\title{
ISLAMIC BANKING AND FINANCE IN THE 21ST CENTURY \\ SELECTED ISSUES IN HUMAN CAPITAL DEVELOPMENT
}

\author{
Mohamed Aslam Haneef*
}

\begin{abstract}
Islamic Banking and Finance (IBF), both in theory and practice, has made great strides over the last 40 years. However, it is not spared from criticism, much of it relating to issues of 'Islamicity' and 'originality' of mainly IBF practice. One major reason underlying these issues relates to the quality of human resources related to IBF. This article first presents some of the tensions that exist in contemporary IBF. These tensions include debates within the theoretical discourse regarding preferred instruments in IBF. The article also highlights some problems that occur due to the divergence between the theory of IBF and with its practice, leading to a general perception that IBF merely duplicates conventional finance rather than offering any true alternative. The article argues that to resolve these tensions, greater emphasis must be placed on creating qualified human capital at all levels of the IBF discipline and industry. In addition, IBF would be better served if Islam and its sharīah were viewed as a civilisational framework, rather than a narrow figh/law focus. Having a civilisational understanding of Islam, its shari'ah and the Islamic heritage on the one hand, as well as a genuine understanding of modern economics and finance on the other, are necessary pre-requisites to enable IBF to play its role in serving the ummah more effectively in the twenty-first century. Genuine Islamisation of knowledge would produce the human capital desired.
\end{abstract}

\section{Introduction}

Islamic banking and finance (IBF) has become one of the main visible features of Islamic resurgence in the latter part of the twentieth century. It has also become, rightly or wrongly, the main practical manifestation of Islamic economics and of the 'Islamisation of economics/knowledge' project that began in the mid 1970s. The track record of IBF is indeed impressive and deserves to be acknowledged. From the establishment of the first private commercial bank in 1975 in Dubai, there are now about 300 Islamic banks and 90 takăful companies in over 75 countries. One

* Prof. Dr Mohamed Aslam Haneef is Professor of Economics at the International Islamic University Malaysia (IIUM). 
can also witness the high growth in global shari 'ah-compliant assets, estimated at US\$1 trillion with a growth rate of 15-20 per cent per annum. ${ }^{1}$

Despite the great strides made, there have also been criticisms of Islamic banking, both at the conceptual, but mainly at the 'practice' level. The main argument goes back to inter-connected issues of 'islamicity' and 'originality' (of products and instruments), preferences of products and instruments (especially between academics and practitioners), qualifications of those involved in the IBF industry, as well as the role and competency of the shari 'ah advisory process. While the world is still trying to come to terms with the exact magnitude of the 2008-09 global financial and economic crisis, it has also given an opportunity for the proponents of IBF to put their case forward as an alternative to the dominant capitalist paradigm. Important players have claimed IBF to be the saviour of not only Muslims, but humanity as well. These claims have to be subjected to honest evaluation.

This article will discuss selected issues that involve human capital development in IBF. It will try to address some concerns and debates within the conceptual/ theoretical discourse as well as those concerning the conceptual/theoretical-practical relationship. While many issues can be discussed, this article will try to focus on some interconnected ones that have direct concern to the education process as well as content of curriculum that will help take IBF forward.

\section{Tensions in Contemporary IBF}

\section{How Islamic is IBF?}

A question that annoys many in the field of IBF, especially those in the industry, are the constant doubts concerning the 'islamicity' or authenticity of IBF. Aside from the criticism on practical aspects of IBF, academics and scholars involved in Islamic economics, banking and finance, too, have become the target of censure. This is mainly because quite a few academics are also involved in the 'shari' ah advisory process', which is seen by critics as merely 'legitimising/justifying' practices being put forward in the market. However, even within the academia, there is great debate about the direction of IBF and the preferences of instruments being used in theory as well as in practice. In the early 1970s, when Islamic economists started writing about Islamic economics, IBF was one area addressed. The writings as a whole put forward a very different IBF than what we see today. The picture was one that had a more 'developmental' approach and goal. However, by the late 1980s this approach, and those from among the academia who promoted this approach, were marginalised and replaced by those who were more 'practitioner friendly'. Also, many Islamic economists who may have been initially involved in the IBF industry, 
were 'replaced' by jurists and accountants, who were seen to be more 'qualified' and who understood the needs of the industry better than the 'theoretical' economists.

One controversial area regarding the practice of IBF that has come under scrutiny is the role of members of the 'sharī 'ah advisory boards' that govern individual Islamic banks and their views regarding Islamic banking today. Even at the relatively 'popular' level, London-based writer Carla Power in an overly critical article presents the following observation that has become an increasing trend in society:

But how truly Islamic is the Islamic finance these men promote? To their critics, many are nothing more than rent-a-sheikhs, willing to give the spiritual nod to just about any financial product for the right price. ... One recent study from the AAOFI (Accounting and Auditing Organization for Islamic Financial Institutions) concluded that 85 percent of bonds marketed as sharia-compliant were illegitimate. And the fees many of these scholars take in - at times, six figures for a single decision - only add to such critiques. ${ }^{2}$

Central to this questioning of 'authority' in IBF practice is the issue of who should sit on these advisory boards, what their qualifications should be and what should the scope of their duties be. In the case of Malaysia, while there is no explicit requirement for Islamic law/fiqh qualifications, the convention is that 'sharī'ah advisors' should be trained in Islamic law. While not questioning the sincerity of these scholars, the issue may be more concerned with the qualifications and exposure of these scholars and hence their ability to give sound $\operatorname{sharl}^{-}$'ah advice (as opposed to Islamic law advice). We will take this up later.

\section{Modifying Instruments or Going for More Fundamental Institutional Changes}

A larger issue is whether Islam and the modern economy can be reconciled at all. Is it enough to create banking products that mimic those of traditional finance but also meet the letter of Islamic law? Or must the goals of the financial system itself be reworked fundamentally? ${ }^{3}$

One major criticism of Islamic banking has been that it is modelled after the interest-based (especially commercial) banking system. Hence, the role and function of banks have primarily been retained while focus has been on creating 'sharì' $a h$ compliant instruments' (seen by the critics as more expensive duplicates) to replace the interest-based instruments of conventional banks. Critics as early as 1986 like Ziauddin Sardar blame what they saw as 'patchwork economics' stemming from the misplaced 'Islamisation of knowledge' agenda. ${ }^{4}$ Sardar argued that since this agenda takes the modern discipline as the reference point and wants to 'seek the relevance of Islam to it', 5 this can only result in patchwork and 'bad imitations'. This criticism could have some truth to it if one was to take the 'simplistic and shallow' understanding of 'Islamisation of knowledge' that seems to have prevailed among 
some proponents of Islamic banking, and consequently practitioners of Islamic banking and finance.

What we mean by this simplistic and shallow understanding of 'Islamisation of knowledge' is emphasis on narrow areas of economics, in this case banking and finance instruments, without giving due emphasis on foundational issues. Failure to give attention to these foundational issues that would include discussion of a philosophy of Islamic economics and finance could easily lead writers to accept the banking institution as is, without understanding the history and foundations of modern banking itself. These critics thought it necessary for Islamic economists to have asked even more fundamental questions like whether there was a need for banks as we know them today, as an answer to solve problems in Muslim societies today. Hence, according to these critics, what has been attempted is to mould conventional banks into Islamic shape by 'purging them of interest' and replacing it with profitloss sharing arrangements.

From the experience of Islamic banking over the last 20 years or so, we now see that this has actually not happened. Instead of equity instruments like murābahah and mushärakah, Islamic (commercial) banks have actually focused almost exclusively on debt instruments such as muräbahah and bay 'mu'ajjal or bay 'bi-thaman 'äjil that critics say seem to be very similar in operation to conventional practices, and hence familiar to practitioners. While generally accepted by almost all scholars as being an acceptable Islamic contract, Islamic economists initially argued against these debt instruments being given too much prominence by Islamic banks, seeing relatively less developmental impact. While Sardar criticised Islamic economists for not asking the 'right' questions, practitioners sidelined Islamic economists for criticising them. All the while, the problem lay in the approach of accepting the banking institutions as they were and trying to mould them into Islamic shape by 'Islamising' the instruments. Only now, rather than equity instruments, some Islamic bankers have succeeded in focusing almost exclusively on debt instruments with the backing of 'sharì' ah advisory boards' made up almost exclusively of fiqh trained scholars. Whether we agree with Sardar or not, the point to note is that Islamisation efforts, if not inclusive of foundational, methodological and epistemological concerns relevant to economics and finance, will end up making Islamic economics a branch of western economics and may not live up to the claims that IBF will be the saviour of humankind against crises like we are facing now. ${ }^{6}$

\section{IBF in Theory vs IBF in Practice}

The tensions that existed continue to exist today between the ideals of IBF initiated by Islamic economists in the 1960s and early 1970s, with the practice of IBF spearheaded by bankers, with the support of some jurists and economists. It will continue to be an important area of debate and criticism. As mentioned previously, 
while the early Islamic economists saw IBF as an extension of Islamic economics, and hence, having developmental goals, practitioners with the support of some jurists saw IBF as primarily a commercial enterprise as in modern banking and finance, and hence, replicating its practices. Unfortunately, 'sharī'ah compliance' has increasingly come to mean the minimum legal standards that are permissible, rather than aiming to determine 'preferred' options that would have a greater socioeconomic impact on society as a whole in relation to developmental goals such as poverty eradication, job creation, entrepreneurial development and greater sharing and distribution of benefits (and losses).

Even if we accept the less preferred options of debt-based instruments (like BBA and bay ' al- 'inah-based contracts in Malaysia) the theory-practice divide is further aggravated when the practice of debt-based IBF does not necessarily follow the requirements of the theory of debt-based IBF. A recent High Court judgment in Malaysia ${ }^{7}$ gave a verdict that stated explicitly that the "BBA as practiced in Malaysia was not a bona-fide sale" and for all practical purposes was more like a loan contract. On appeal (the written judgment is still pending), the presiding judge found that the High Court judge above had erred in his judgment, since the "BBA is a sale contract and not a loan". A simple reading of this decision indicates that both judgments seem to be talking about different things: the appeal court was referring to the theory of $B B A$, while the High Court was referring to the practice of $B B A$ in Malaysia. Why is there a departure between theory and practice and how were the practices 'justified' by the shari' 'ah boards? This has brought into question the whole process of shari 'ah advisement and the qualifications of members of these boards. While we may not agree with the accusation of the 'rent-a-sheikh' view, we can certainly see shortcomings in the present shari ' $a h$ advisement process and in the limitations of the knowledge exposure of the parties involved, maybe even including the learned judges on matters relating to the BBA contract.

\section{The IBF Advisement Process: Breaking Free from Equating the Sharī'ah with Law}

The Islamisation of the banking and finance industry has been a great success story for showing the world that Islam and the shari ${ }^{-} a h$ can contribute positively to solving modern finance needs. However, there seems to be resistance to 'true or holistic Islamisation of economics/finance' from within the circle of some Muslim scholars, who are mainly trained in fiqh (mistakenly narrowed to mean law). Many of the banking products are designed by bankers who are mainly trained in conventional finance or some other conventional area, but whose knowledge in Islamic heritage and Islamic economics/finance may be limited or even non-existent. They rely on shar $\bar{l}^{\prime} a h$ (misread legal/law) scholars trained in fiqh and to a lesser extent in ușül al-figh/jurisprudence to give verdicts on these sometimes rather complicated 
financial products. Islam and its shari $\bar{i}^{\prime} a$ are reduced to the legal dimension rather than seeing them within a greater civilisational framework.

These scholars with due respect to them, are still in 'legal' mode, i.e. focused exclusively on legal reasoning. They are greatly in demand to make ijtihād on contemporary economics/finance issues and to produce alternative shari 'ahcompliant instruments. While their sincerity is not questioned, the 'originality' of the products and their implications for society sometimes are. ${ }^{8}$ Besides the 'duplication' criticism, there is a much deeper soul searching that needs to be done by all involved. Is it possible for us to truly develop genuine Islamic alternatives if we are not trained in economics/finance as well as the heritage? Is it possible to look at instruments from the purely legal reasoning angle dealing with contracts, without also knowing the economic and social implications of those instruments and how development as a whole is served? ${ }^{9}$ Can we truly claim that the instruments that are being put forward are genuinely 'serving public interest' if we do not give the required attention to ethical (and not just legal) issues in the views that we make? Should there not be a preference for more ethically preferred choices in IBF? Why are we satisfied to just have the 'minimum legal requirement' as the standard that we want to follow?

While bankers and practitioners make no claims to being Islamic experts, in most cases, they determine the direction of the product and product development. On the other hand, the legal experts whose knowledge is limited to Islamic law of contracts are asked to evaluate these products and give an opinion. Certainly it is unfair to ask these scholars to go beyond their fields of expertise. Hence, while the instruments may be 'fiqh or legally compliant', they may not meet the requirement of being 'shari 'ah compliant' in the true sense, since the shari 'ah is much wider than law and consists of 'guidance' (including laws, values, norms, principles etc.). Limiting knowledge of the sharī' ah and the turāth (heritage) to mere figh discussions and reasoning may not do justice to Islamic economics, banking and finance. In the case of economics, banking and finance, we are talking about a social science, maybe a part of Ibn Khaldun's 'Ilm al- 'Umrān (lit. 'Science of Civilisation') that tries to understand, analyse and describe human interaction and choices made in areas of allocation of resources, distribution, exchange and finance (among others). In the last category, it will also involve the creation of instruments, but should not only be limited to this.

Similarly, if we talk of the methodology that needs to be adopted, the discipline of ușūl al-fiqh (understood as more legal reasoning) has to be distinguished from ușūl al-iqtisād, the latter being a much broader area of 'the foundations/methodology of Islamic economics'. Rather than only limited to the legal dimension of the heritage and its methodology, ușūl al-iqtișād would include the Islamic worldview, ușūl al-'ilm (sources or foundations of knowledge), fiqh and ușül al-fiqh, ușül al-dìn, 
history, analytical techniques and many other areas of knowledge that would enable holistic decisions to be made, decisions that will enable the 'more preferred choices to prevail and decisions that will take into consideration a wider end-result that represents public interest and civilisational goals of Islam and its shari ${ }^{-} i a h .{ }^{10}$ Hence the knowledge of the heritage required in order to develop contemporary Islamic economics, banking and finance must be more than just the narrowly 'mis-defined' shari 'ah (legal) sciences. One of the greatest maladies to befall the Muslims is this 'corruption' of original rich meanings of terms and concepts in the Islamic worldview to narrow meanings. ${ }^{11}$

As far as modern economics is concerned, meaningful Islamisation cannot occur without some level of 'critical' understanding of the functioning of the modern economy, its system and constituent elements. We state 'critical' because the modern system has to be evaluated from an Islamic framework or perspective. Knowledge in this category would include areas such as economic history (both of thought and practice), statistics (including today's econometrics), theory (both macroeconomics and microeconomics) and economic sociology (which may include other social sciences). One must also be prepared to include elements of sociology, logic, psychology and philosophy in its connection to economics. In the context of developing Islamic economics, it would be necessary for us to 'master' these areas of knowledge, but always with reference to the Islamic perspective. In terms of economics, banking and finance, this would mean understanding contemporary advances in these areas critically.

Meaningful Islamisation implies that the Islamic economist or the Islamiser of contemporary economics, banking and finance must know what is acceptable, what needs modification (what to be done and how to do it), what is to be rejected (what and why) and to be able to relate these to contemporary realities as well. It is certainly a tall order and one that does not seem possible if we continue to move in the present way contemporary Islamic banking products are being developed. While the products are developed and presented by mainly western-trained economists/ bankers, shari ' $a h$ scholars are asked to evaluate them. The latter are not necessarily familiar with the running of the economics and finance sectors and their knowledge in areas of philosophy/methodology (with reference to ușūl al-iqtișād) leaves a lot to be desired. If people are questioning present-day products, it is not necessarily only for their legal validity but also for their ethical implications. It is a valid question to ask whether the present two parties involved in the creation of Islamic financial instruments (conventional bankers and sharī ah/legal scholars) should be left alone or some other type of boards need to be set up to act as checks to the shari ah boards!

If one interprets this as a call for the inclusion of Islamic economists, a point of caution is called for. Even among the Islamic economists, we have to be honest about our ability to truly Islamise economics. While many economics/Islamic 
economics programmes do offer courses in the heritage, these are usually in fiqh and to a lesser extent in ușül al-fiqh. In addition, these courses are taught in ways that are 'unconnected' to economics/ finance. The level of discourse in methodology and philosophy of science leaves a lot to be desired in these programmes. Islamic economists themselves keep referring to the heritage in terms of $f i q h$ and law. This brings us to the issue of the human capital challenges faced.

\section{Genuine IBF Needs Genuine Islamisation: The Role of Education and Training}

\section{Compulsory (Farḍ al- Ayn) Knowledge in IBF: Islamic Heritage and Modern Economics/Finance}

The main lesson gained from 30 years of IBF is that no creative synthesis between the Islamic heritage and modern economics, banking and finance to create an Islamised body of knowledge in the form of textbooks can be produced unless we are able to create a new breed of scholars and practitioners. Right now, despite much progress, the gap is still there. The gap is there not because no one has pointed out what needs to be done. The gap is still there because short-term gains that can make IBF 'seem to be successful' are taking precedence over a longer-term view on what we want IBF to achieve. These longer-term goals cannot be seen without an understanding of both the heritage and modern economics and finance and their philosophical foundations. Genuine Islamisation of knowledge efforts will have to provide this dimension in the educational curriculum.

At present, many modern western-trained Muslim social scientists are not able to appreciate the philosophical and methodological issues underlying their own disciplines, let alone having any meaningful exposure to the Islamic legacy. Their training has created, in many cases, mediocre scholars who may fail to understand the foundations of their disciplines, not to mention any ambition of 'mastering' their disciplines as demanded by the 'Islamisation of knowledge' agenda. This sad state of affairs is - slowly but surely - changing for the better, with more scholars realising that foundations of western disciplines and exposure to Islamic heritage are necessary for any attempt at genuine Islamisation of knowledge and in developing genuine IBF.

In other cases, their training may have created 'masters' of modern disciplines, who have also, maybe unconsciously, become entrapped in the existing frameworks of those disciplines, i.e. they may not approach issues from a genuinely Islamic perspective. It may be pertinent to keep in mind that although many Muslim academics may also have advanced degrees in specific areas of modern disciplines, their knowledge of Islam, its worldview, of Islamic philosophy and methodology 
relevant to their disciplines and of the 'Islamisation of knowledge' may greatly differ from one academic to another. In extreme cases, the latter may even be next to non-existent.

The above scenarios are not surprising since most economics and finance programmes in western universities today hardly discuss philosophical and methodological issues in economics. The underlying assumptions of mainstream neoclassical-Keynesian economics (such as those associated with the rational economic man and his maximisation goal) are accepted as 'given', while most - if not all - attention is placed on mastering the latest quantitative techniques (now available in software packages) and applying these to 'analyse data'. In addition, mainstream neoclassical methodology and its 'scientific methods' (model building with a primarily predictive goal) are accepted as objective and correct, with an overwhelming attention paid to technical procedures and application of quantitative techniques to solve mathematical equations, without ever questioning the philosophical underpinnings and ideological foundations of these methods and techniques and the theories they are used to promote. Critically evaluating these philosophical foundations is what genuine Islamisation of knowledge is all about, and it would seem the logical area to allocate resources, both financial and human. If nothing more, we should at least learn from the developments in the west where an increasing number of economists and philosophers of science are questioning the entire framework on which the dominant paradigm of neoclassical economics rests. ${ }^{12}$

Scholars keen on the Islamisation of economics and finance would certainly benefit from reading the material coming out from scholars and graduate students in western universities, who in many respects are much more advanced and profound in their critique of mainstream neoclassical economics. IBF needs to devote more resources to creating a new type of scholar who will be able to be genuinely innovative, keeping in mind the developmental and civilisational goals of contemporary Muslim societies. The scope of knowledge that will be required to meet these challenges must be widened, while areas that are considered to be irrelevant like history and philosophy need to be part of the curriculum that is emphasised.

Contemporary Islamic economists should also be willing to learn from history, both of Muslims and of Western Europe. Our early scholars who came across writings of the Greeks for example were very selective on what they reviewed, worked from 'Islamic perspectives' i.e. with understanding of the Islamic worldview and hence, were very careful and successful in Islamising knowledge. Also, many scholars chose to write works on classification of knowledge, so as to place new bodies of knowledge within an overall schema. If we look at the history of western economic thought, it is very clear that methodological and philosophical concerns were discussed, debated, and developed from the time economics was a part of theology and moral philosophy during the period of the scholastics in medieval 
Europe during the thirteenth to fourteenth centuries and also very clear in the writings of the mercantilists and physiocrats of the fifteenth to sixteenth centuries. ${ }^{13}$ Debates on methodology clearly affected the writings of the political economists of their time. Many major writers in the western economic tradition also wrote on methodological issues such as John Stuart Mill.

Until there is a similar realisation of foundational, including methodological issues among contemporary Islamic economists - as there has been in our own tradition in the past, and in western scholarship during the developmental stages of western economics, and again over the last 30 years in the West - we may continue developing IBF along the same path. There is a need to make a long-term commitment to knowledge and scholarship now. This could enable IBF to genuinely take up the challenge of being the alternative to the dominant paradigm and to genuinely contribute to achieving the civilisational goals of Islam as we face the challenges of the twenty-first century.

\section{Notes}

1. "Islamic Banking \& Finance at the Crossroads of Global Financial Crisis: The Way Forward", Keynote Address by Dato’ Mohd Razif Abdul Kadir, Deputy Governor, Bank Negara Malaysia at the IIUM Institute of Islamic Banking and Finance, 20 March 2009, Kuala Lumpur. For a detailed elaboration on the development of IBF, please see Hossein Askari, Zamir Iqbal, and Abbas Mirakhor, New Issues in Islamic Finance and Economics: Progress and Challenges (Singapore: John Wiley and Sons, 2009), especially Chapter 1.

2. "Faith in the Markets", Foreign Policy (January-February 2009), available online at http://www. foreignpolicy.com/story/cms.php?story_id=4596 (accessed on 2 June 2009).

3. Ibid.

4. See Ziauddin Sardar, Islamic Futures (London: Mansell Publishing, 1986). Sardar was one of the earliest critics of Ismail Faruqi's Workplan on Islamization of Knowledge. While harsh, and in places overly so, a few of these criticisms were actually incorporated in modified versions of the workplan and in later works that developed on the IOK agenda. See Mohamed Aslam Haneef, A Critical Survey of Islamization of Knowledge (Kuala Lumpur: International Islamic University Press, 2009, 2nd ed.).

5. This is taken from step 5 in Ismail Faruqi's Islamization of Knowledge: Problem, Principles and the Workplan (Herndon VA: IIIT, 1982).

6. While this is seen as counter-productive by critics like Sardar, some scholars like Monzer Kahf, are of the view that Islamic economics becomes a part of the science of economics just as Marxist or capitalist economics. It is to be studied within the area of economic systems but based on the assumptions of Islamic axioms, values and ethics, just as Marxist and capitalist economics are studied within their own paradigms. While this is not the place to evaluate this position, the present writer may not fully agree with this view as it may be wrong to equate the nature and scope of Islamic economics with its contemporary western secular counterpart. See Monzer Kahf, "Islamic Economics: Notes on Definition and Methodology", Review of Islamic Economics 13 (2003), 23-48.

7. See Datuk Abdul Wahab Patail, High Court Malaysia, Commercial Division, 18th July 2008. Judgment on various suits brought by a few Islamic banks against clients. Suit No: D4-22A-067-2003, Suit No: D4-22A-215-2004, Suit No: D4-22A-1-2004, Suit No: D4-22A-185-2005, Suit No: D4-22A-399-2005, Originating Summons No: D4-22A-395-2005, 
Writ No: D4-22A-166-2006, Writ No: D4-22A-167-2006, Writ No: D4-22A-178-2006, Suit No: D4-22A-192-2006, Writ No: D4-22A-203-2006, Writ No: D4-22A-204-2006.

8. See Saiful Azhar Rosly, Critical Issues on Islamic Banking and Financial Markets (Kuala Lumpur: Dinamas Publishing, 2005) which represents newspaper and magazine articles written by the author over the period 1994-2005. Most of the examples used refer to Malaysia, but many are also reflective of the issues/problems in IBF generally. In the book, the author raises his concerns in terms of the 'originality' of IBF and how its proponents have to ensure that the confidence of consumers towards IBF is maintained by ensuring that the IBF industry does not become a mere 'duplication' industry, i.e. one that justifies the conventional framework.

9. On this issue, M.N. Siddiqi pointed out the importance of understanding the 'macro-fiqh' dimensions of IBF on the economy and society as a whole as opposed to the 'micro-figh' qualifications of most legal scholars. See his "Shari'ah, Economics and the Progress of Islamic Finance: The Role of Shari'ah Experts", IIUM Journal of Economics and Management 15, no. 1 (2007).

10. On the discussion of ușūl al-iqtișād see Mohamed Aslam Haneef and Hafas Furqani, "Ușūl alIqtișād: The Missing Dimension in Contemporary Islamic Economics", Readings in Islamic Economics and Finance (Sintok: Universiti Utara Malaysia, 2007).

11. See Syed Muhammad Naquib al-Attas, Prolegomena to the Metaphysics of Islam (Kuala Lumpur: International Institute of Islamic Thought and Civilization [ISTAC], 1995).

12. In the last three decades there has been a growing disenchantment with the dominant paradigm of mainstream economics. Alternative views are being put forward and heterodox views are having a renewed life. See for example the Heterodox Economics portal at www.hetecon.com and the Post- Autistic Economics website at www.paecon.net.

13. While numerous books on the history of western economic thought can be found, one monumental work that should be read by all Islamic economists eager to study the interface between economic reasoning and western thinking in general, is Karl Pribram's A History of Economic Reasoning (Baltimore: Johns Hopkins University Press, 1983). 